\title{
How did Taiwan's Critical Election Changed China's Taiwan Policy in the Early 2ooos: A Modified Two-Level Game Analysis
}

\author{
Do Young Gong and Eunbong Choi
}

This study explores how Taiwanese domestic politics in the 1990s influenced China's Taiwan policy in the early 2000s. To illustrate this, this paper applied Robert Putnam's discussion of the linkage between domestic politics and international politics using the two-level game theory. Using a two-level analysis, this paper analyzes how Taiwanese social cleavages in the 1990s led to a change not only in its domestic politics but ultimately in China's Taiwan policy. Taiwan's social cleavages such as ethnicity and national identity have erupted throughout democratic transition in the 1990s. These social cleavages were also reflected in the political party system. As a result, political parties divided into two camps, and the unification or independence issues became the borderline between them. These points culminated in the 2000 "critical presidential election." The 2000 Presidential election resulted in Taiwan's strengthened bargaining power on the issue as well as its reduced win-set. The election also resulted in China's bargaining power becoming relatively weak. In order to expand the possibility of consensus with Taiwan instead of using military threat, China expanded its win-set first and then interacted both with Taiwanese politicians from the Pan-blue camp and with Taiwanese businesspersons in China for the purposes of expanding Taiwan's win-set.

Key Words: Cross-Strait relations, Two-level game theory, Win-sets, Unification, Critical election

* Do Young Gong (dy920109@gmail.com, First author) is a Master's graduate in Political Science and International Relations at Ewha Womans University. Her research interests include international relations, cross-Strait relations and East Asian regional politics. Eunbong Choi (ebchoi@ ewha.ac.kr, Corresponding author) is a Professor of Political Science and International Relations at Ewha Womans University. She received her Ph.D. in Political Science from Ohio State University, and her fields are Comparative Politics, Northeast Asian Studies, and Japanese Politics.

This paper is based on Do Young Gong's Master's dissertation, and was presented at The Korean Political Science Association and International Studies Association Joint Conference and International Studies Association-West 2018 Conference. The authors greatly appreciate the thoughtful comments and suggestions of the anonymous reviewers, as well as the valuable comments from discussants at conferences. 


\section{INTRODUCTION}

This paper begins with a question: why did China change its Taiwan policy after the Taiwanese 2000 presidential election, when Chen Shui-bian from the pro-independence party was elected? Throughout the 1990s, China was sensitive to Taiwan's pro-independence movement, which resulted in several military threats. ${ }^{1}$ However, after Chen Shui-bian was elected in 2000. China adopted a conciliatory attitude toward Taiwan, emphasizing cross-Strait economic relations. China even modified its interpretation of the One-China principle. ${ }^{2}$ This study explores how Taiwanese domestic politics in the 1990 s influenced China's Taiwan policy in the early 2000s by borrowing Robert Putnam's discussion on the linkage between domestic politics and international politics in two-level game theory.

This study focuses on China-Taiwan relations only. While previous studies explain that the United States has played one of the most influential and significant roles in cross-Strait relations, the US has recognized China as the only representative Chinese government since 1979 and has interacted with Taiwan very little (Kan 2014, 1). During the late 1990s and the early 2000s, Taiwanese leadership explicitly claimed Taiwan's independence on several occasions; each time, the US sided with China and restrained Taiwan. However, China's Taiwan policy began to change after the Taiwan Presidential election in 2000.

In addition, this paper does not explicitly account for the time period or change in Chinese leadership. The focus of this study is the early 20oos, under the latter half of Jiang Zemin administration and later, Hu Jintao's leadership. China's main goal in this period was to improve people's living standards and the CCP's legitimacy, to avoid major economic, social, environmental and political crises (Tung 2003, 23). This can partly account for China's moderate Taiwan policy in this period. However, this paper aims to reveal why China's Taiwan policy was

\footnotetext{
${ }^{1}$ In February 2000, right before Taiwanese Presidential election, China issued "The Taiwan Question and Reunification of China” and expressed China's will to use force toward any Taiwanese independence movement. (www.china-embassy.org/eng/zt/twwt/White\%20Papers/t36705.htm). In addition, three days before election, Zhu Longji, the premier warned that anyone who pursues Taiwan independence would end badly (People's Daily 2000, March 16).

${ }^{2}$ In July 2000, Chen Qichen, the vice premier of the State Council met with Taiwanese press, and suggested a new perspective that China and Taiwan do not have to bring up discussions on the interpretation of the One-China principle for now. In addition, He mentioned that SEF and ARATS could negotiate the "three links issues" first, while putting aside political issues (Su, Chi, 2017, pp.189-190). Jiang Zemin stipulated a new definition of the One-China principle in the report at the $16^{\text {th }}$ Party Congress in 2002 that both the mainland and Taiwan belong to China (http://www.china. org.cn/english/features/49007.htm).
} 
modified abruptly in particular moments of domestic political change in Taiwan.

There are several previous studies on China's changing policy toward Taiwan in 2000s. Tung (2002a) and Yan (2011) analyzed how China's Taiwan policy has changed over time. These authors historically analyzed the Taiwan policy from its economic reform in the late 1970s to the 16th party Congress in 2002. Hickey (2009) described the "carrots and stick" perspective in China's Taiwan policy. These authors overview the overall practices and changes in China's Taiwan policy, but do not account for which variable led to the policy change. Xin (2009) explained that China's modified perception toward Taiwan led to a more conciliatory approach. Xin also does not account for the causes of this change in perception. Wei (2015) took a constructivist approach to describe the interaction between Taiwan's Kuomintang (hereafter, the KMT) and China from 2000 to 2008 that enabled China's moderate policy. However, his account of the interaction between the two sides facilitates some, but excludes the most important parts of China's moderate policy. Chen (2012) explained the impact of Taiwanese domestic politics on a Chinese leader's perception of Taiwan, while comparing Jiang Zemin's impatience with Hu Jintao's patience regarding the Taiwan issue. As the Taiwan issue is linked to their own domestic legitimacy, Chinese leaders show impatience if they perceive that the development of Taiwan's domestic politics and its China policy is moving in the direction of proindependence or anti-unification, and show patience in the opposite situation. Chen's focus was to explain the impact of Taiwanese domestic politics on Chinese leaders' perception. Here, the authors try to account for the political linkage between China and Taiwan systematically accounting for the domestic structural political change in Taiwan and its impact on the size of win-set and the bargaining power between two sides, and Chinese ultimate policy change toward Taiwan. Together, these previous studies of China's changes in Taiwan policy explain most factors, or focus on changes in international circumstances and leadership change. While this paper understands the importance of other variables, here it argues that there is an immediate cause for rapid changes in China's Taiwan policy that may be explained through Taiwan's domestic politics.

\section{MODIFIED TWO-LEVEL GAMES THEORY}

In international relations, international negotiation studies have been developed based on realism and liberalism. These are representative paradigms of international political theory. In the realistic paradigm, groups of negotiators who have specific national interests to be achieved and to be maximized 
represent states. Alternatively, in liberalist tradition, the goal of negotiation is to solve common problems that the parties face and to try to find solutions to those problems that will benefit everyone (Hopmann 1995, 29-30).

Rosenau (1966) was among the first to systematically study the linkage between domestic politics and international politics by introducing the concept of "linkage politics." To explain the interactions between an international environment and a domestic system, he created a "linkage framework" which constitutes 144 cross terms and denounced traditional international theories which had assumed either of a state or an international system as the unit of analysis. Moreover, consideration is taken into account that domestic organizations or societies are influenced by both an international system and influences on that system at the same time. He also emphasized the importance of theorizing interactions between the systems.

Domestic influences on foreign policy decision making have also been studied in comparative foreign policy studies. The Comparative Research Project on the Events of Nations (CREON), edited by East, Salmore and Hermann in 1978, placed emphasis on domestic decision making structure and process, political system and leadership in a state's foreign policy decision making. Katzenstein and Krasner (1978) explored the structure of a state, and explained that both domestic and international pressure should be considered together. They divided states into strong and weak ones, based on whether each state had any sovereign authority to play a leading role in decision-making. However, this classification only dealt with institutional and bureaucratic aspects of states, and does not explain "politics" which include political parties, social class, interest groups, legislators or public opinion and elections. Keohane and Nye (1977) described the interactions between international actors - non-governmental organizations, international organizations, multinational corporations, and labor organizations -- and societies of each state. They argued that international reality could not be explained with state-oriented perspective. Walton and Mckersie (1965) introduced behavioral theory of social negotiations and commented that the unitary-actor assumption is often radically misleading. They suggested a possibility to link the internal and external spaces of a group in negotiation studies.

Two-level games suggested by Putnam (1988) specified a formal theoretical attempt to link domestic politics and international politics. He also analyzed how the domestic factor of a state can affect the consequences of international negotiations. Domestic politics of a state not only influence its own foreign policy making but the negotiation process with another state as well. In addition, negotiation can consequently affect foreign policy of the other state. As this 
study explores how domestic political changes in Taiwan influenced China's Taiwan policy, it applies Putnam's discussion on the linkage between domestic politics and international relations. In two-level games theory, at the national level, domestic groups pursue their interests by pressuring their government to adopt favorable policies, and politicians seek power by constructing coalitions among these domestic groups. At the international level, national governments seek to maximize their own ability to satisfy domestic pressures, while minimizing the adverse consequences of foreign developments. Central decisionmakers can ignore neither of the two games, so long as their countries remain interdependent, yet sovereign.

At the international level (Level I ), the negotiators from each state bargain, leading to a tentative agreement. At the national level (Level II), separate discussions are held within each group of constituents about whether to ratify an agreement. The ratification process in Level II can entail a formal voting procedure as well as an informal decision making process to endorse or implement it. The ratification is simply voting up or down, and any modification to the Level I agreement counts as a rejection, unless that modification is approved by all other parties to the agreement. The concept of "win-set" is a given Level II constituency as the set of all possible Level I agreements that would gain the necessary majority among the constituents when simply voted up or down. Win-sets are important in determining the consequences of negotiation. Larger win-sets make Level I agreement more likely and the relative size of the respective Level II win-sets will affect the distribution of the joint gains from the international bargain. Smaller win-set of a state guarantees stronger bargaining power. The size of the win-set is determined by three factors: the distribution of power, preferences, and possible coalitions among Level II constituents; the Level II political institutions; and the strategies of the Level I negotiators.

Moravscik pointed out three drawbacks of the discussion: it did not account for the negotiator's preference; negotiations can be taken place between a number of states and a state, or among states; the theory does not consider the existence of the international system. In particular, Moravscik's second point describes that there have been many efforts to modify the theory to embrace more actors in the negotiation process.

Kim (2001) modified the theory, and brought the existence of a hegemon into the discussion. A two-level games model under the hegemonic situation can be seen as a process in which three games are played simultaneously. Three phases of games include the bargaining between two states in the international level (Level I), domestic constraints of the domestic ratification phase (Level II ), 
and the interest of hegemonic state. The key to the two-level games model in the hegemonic system is that the hegemon's policies perform as a facilitator of cooperation between the negotiating parties. Thus, even in unlikely negotiations, the size of win-set of the negotiating countries can be expanded according to the preference or pressure from the hegemonic country, and makes the cooperation possible.

Patterson (1997) suggested the three-level games model when analyzing the bargaining process in the General Agreement on Tariffs and Trade (GATT) Uruguay Round, which includes the domestic level, the European Community level, and the international level. The bargaining process took place at both domestic and international levels, but there was an additional play at the European Community level. Member states attempted to achieve domestic goals while simultaneously pursuing cooperative integration. Thus, Patterson included the unique structure of the EC to Putnam's two-level game, and expanded to a three-level interactive game, in which negotiations at the domestic, community, and international levels affect policy options at each of the other levels.

Jung $(2002,2006)$ pointed out that the concept of level is problematic, because it implicitly limits the discussion to inter-state negotiation. However, negotiations do not take place only in inter-state relations but various levels of group-relations. In addition, during an international negotiation each party in the process can be constituted with any of the following: two or more states, non-governmental actors, corporations, etc. Thus, Jung suggested a new concept "face" to replace "level", and explained that the negotiation process is divided into two, in which the representatives of $\mathrm{X}$ and $\mathrm{Y}$ play an external game, and various actors constituting X proceed an internal game. He analyzed the 19931994 US-North Korean nuclear dialogue and he saw North Korea as a unitary actor.

This study borrows the discussion of two-level games theory to analyze relations between Taiwan's socio-political changes and China's Taiwan policy. Here, this paper employs the 92 consensus $^{3}$ between Taiwan and China as our Level I negotiation and the development of Taiwan's social cleavages and changes in political parties regarding One-China policy in 1990s as our Level II negotiation. Using this framework, this paper investigates how Taiwan's domestic policy led to a change in bargaining power of Taiwan and China, how changes in power affected the negotiation, and the strategy that China adopted in response.

Most international negotiations are conducted between delegates from both

\footnotetext{
${ }^{3}$ China and Taiwan reached an agreement that both sides adhere to one China, with respective interpretations in 1992
} 
states. These delegates not only bargain with each other but with their own domestic groups. In this case, however, only Taiwan has meaningful domestic space, but changes in the size of its win-set is not the result of any strategies from its leaders, but of domestic political changes. Thus, this paper does not focus on the conflicts between, or strategies of the negotiator and domestic coalitions.

However, there are two limitations to applying Putnam's theory to cross-Strait relations. First, Putnam mostly focused on a state's strategy to minimize its winset and to expand its counterpart's win-set, ignoring any discussion of when and how a state expands its own win-set. Second, Putnam alludes that negotiations are conducted only between two democracies. Putnam explains exceptional cases that a state expands its win-set in order to facilitate the domestic ratification by using "side-payments" or generic "good-will," but does not clarify when a state tries to expand its win-set although it requires much effort to have a weak bargaining power and to compensate domestic groups at the same time.

In this study, China not only tries to expand Taiwan's win-set, but expands its own win-set for the following two reasons. First, the One-China principle has been utilized as the Chinese Communist Party's (hereafter, the CCP) domestic and international legitimacy and one of the "core interests" of China. Therefore, the action of Taiwan rejecting the One-China principle could become a threat to China's regime. Therefore, while the consequences of a negotiation on other issues affect a state's interest, the One-China principle is an issue, which should not be rejected from China's perspective. Due to the distinct attribute of the issue, China endeavored to reach an agreement rather than to increase its bargaining power. Second, China maintains a party-state system, and there is very little space for domestic groups to engage in the state's foreign policy making. The government has the sole autonomy to decide its own policies. Thus, without any compensation for domestic groups, China can expand its win-set depending on the importance of issues. 
Figure 1 Modified Two-Level Games for Cross-Strait Relations

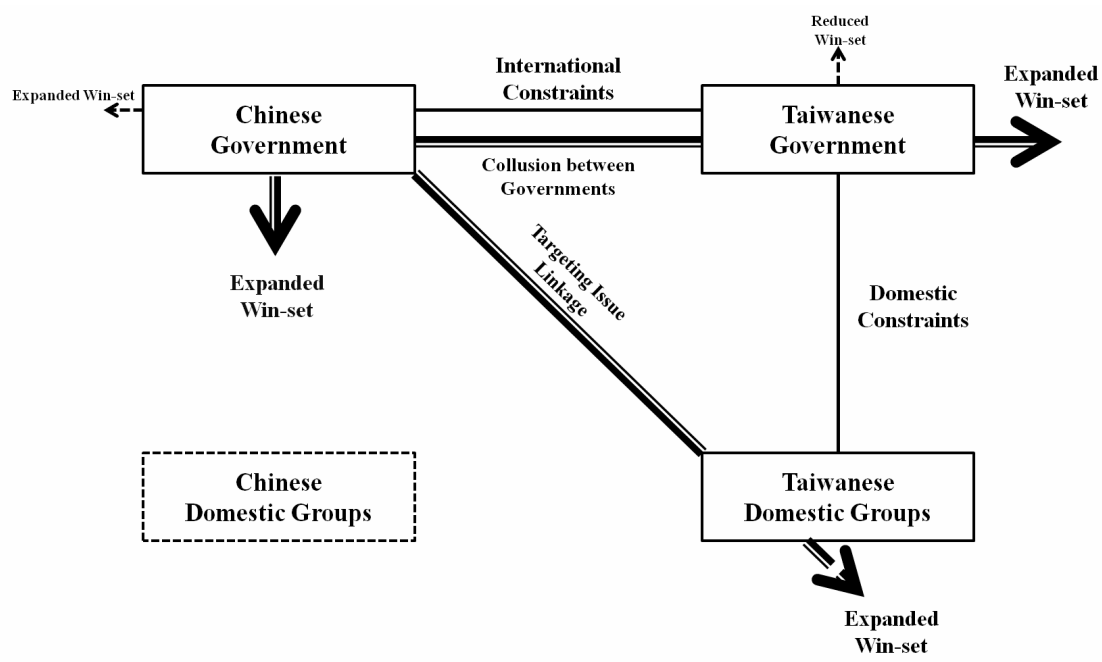

\section{THE 92 CONSENSUS AS LEVEL I NEGOTIATION}

From 1949 to 1955, China's Taiwan policy was based on the China-centered unification by force, which was transformed to the peaceful liberation since the middle of the 1950s (Kim 2010, 124-126). Similarly, Taiwan maintained "anticommunist and resuming state" as their mainland policy basis. It was only after the 1970 s that fissures were beginning to show during the long cooling-off period in the cross-Strait relations. On the first day of 1979, the Chinese government officially issued an announcement titled "The Message to Compatriots in Taiwan," and insisted on peaceful unification under which Taiwan should be 'returned' to the homeland to create "One China in the world." Similar announcements were made by Ye Jianying in 1981, and Deng Xiaoping in 1983.

Taiwan reacted with a "three no" policy: no contact, no compromise, and no negotiation. As Taiwan shut the door tight, there were no exchanges or interactions between itself and China until 1987 when internal changes began in Taiwan. However, Taiwan's international status went into crisis until the end of the 1970s, as it was expelled from the United States, and Japan and the United States switched its recognition from Taiwan to China. Accordingly, the KMT government domestic status also went into crisis, and it conducted a series of democratizing procedures to recover its international status in the 1980s. As it became more liberalized both in economy and politics, Taiwan finally lifted the 
Martial Law and permitted its people to visit their relatives on the mainland in 1987. Cross-Strait exchange and communication could now be developed.

In 1984, Chiang Ching-kuo nominated Lee Teng-hui, a Benshengren, as the candidate for the next vice president. With the formation of the opposition Democratic Progressive Party in 1986, democratization movement was accelerated (Chi 2009, 22). In 1986, the KMT's central standing committee passed a bill to lift the martial law and repeal the law banning the establishment of a new party. The martial law on the Taiwan area was lifted in 1987. In 1991 all the declarations of martial laws based on Temporary Provisions against the Communist Rebellion were invalidated. The temporary martial law effective in Kinmen, Matsu and South China Islands was finally lifted in 1992, which meant the end of Taiwan's authoritarian regime.

After Lee Teng-hui took power in 1988, Taiwan departed from its unrealistic policy to recapture the mainland and instead developed a more realistic one (Han \& Ju 2007, 16). With the emergence of a new international order which put emphasis on economic power, and with Taiwan's economic growth which came to be recognized by the international community, changes in mainland policy were inevitable (Jung 2006, 87). Taiwan has gradually moved beyond its closed and passive stance and sought more clear principles and methods to respond to China (Choi 2011, 16) .

Amid changes in perception and strategy, Taiwan set up an "InterAgency Mainland Affairs Committee" under the Executive Yuan on August 18, 1988. On September 19, 1988, the "State Council Office for Taiwan affairs" in the mainland was established. Both sides now had the agencies in charge of crossstrait relations. Taiwan established the National Unification Council on October 7, 1990, and established the Mainland Affairs Council on January 30, 1991. The abolishment of the Temporary Provisions ended the wartime emergency system. This has also been a major watershed in cross-Strait relations as it has abandoned the wartime law, which defines China as a rebel force and has come to recognize China's political reality.

On March 14, 1991, the National Unification Council passed the Guidelines for

\footnotetext{
${ }^{4}$ At the inauguration ceremony of the 8th President of the Republic of China, Lee Teng-hui said that "if the communist China recognizes the world's trends and the expectations of all Chinese and abandons the use of force in the Taiwan Strait with developing democratic politics and free economic systems, and does not hinder the development of foreign relations under One-China precondition, we will completely open academic, cultural, economic and scientific exchanges between the two sides to build a foundation for mutual respect, peace and common prosperity." https://www.mac.gov.tw/ cp.aspx?n=FF210059589C57F1\&s=454DB66F272B1CE5 (Accessed: 2019. 10. 27).
} 
National Unification ${ }^{5}$, making it a guiding principle for national unification. In the Guidelines for National Unification, Taiwan demonstrated its determination to adhere to one Chinese principle as it had been, and presented four principles ${ }^{6}$ and three stages ${ }^{7}$ for unification. The Guidelines for National Unification shows that Taiwan's policy of reunification with China has completely changed from that of Chiang Kai-shek and Chiang Ching-kuo administrations. Taiwan has abandoned its past position that the Republic of China should be the principal agent of China's reunification, and that the rebel Communist group should be recaptured. Instead, according to the "Three Principles of the People", Taiwan came to emphasize that both Taiwan and the mainland equally belong to one China, they should not deny each other as political entities, and they should be unified. A series of democratic reform and a leadership change of Taiwan served as an impetus for dialogue between the mainland and Taiwan and the 92 consensus. The opposition Democratic Progressive Party stipulated independence in its party platform in 1991 and began to claim one China and one Taiwan in the 1992 parliamentary elections. However, in the early 1990s, Taiwan was in the process of institutional democratic transition, the independenceunification issue had yet to be discussed in the elections.

${ }^{5}$ https://www.mac.gov.tw/News_Content.aspx?n=AD6908DFDDB62656\&sms=161DEBC9EACEA333\&s=E843129F8763CoDD (Accessed: 2019. 10. 27).

${ }^{6}$ 1) Both the mainland and Taiwan areas are parts of Chinese territory. Helping to bring about national unification should be the common responsibility of all Chinese people.

2) The unification of China should be for the welfare of all its people and not be subject to partisan conflict.

3) China's unification should aim at promoting Chinese culture, safeguarding human dignity, guaranteeing fundamental human rights, and practicing democracy and the rule of law.

4) The timing and manner of China's unification should first respect the rights and interests of the people in the Taiwan area, and protect their security and welfare. It should be achieved in gradual phases under the principles of reason, peace, parity, and reciprocity. https://www.mac.gov.tw/en/ News_Content.aspx?n=BEC36A4AoBBo663C\&sms=BF821Fo21B282251\&s=Do017062A39AF1Co (Accessed: 2019. 10. 27).

7 1) Short term-A phase of exchanges and reciprocity: To enhance understanding through exchanges between the two sides of the Strait and eliminate hostility through reciprocity.

2) Medium term-A phase of mutual trust and cooperation: both sides of the Strait should establish official communication channels on equal footing, direct postal, transport and commercial links should be allowed, both sides of the Strait should work together and assist each other in taking part in international organizations and activities; Mutual visits by high-ranking officials on both sides should be promoted to create favorable conditions for consultation and unification.

3) Long term-A phase of consultation and unification: a consultative organization for unification should be established through which both sides, in accordance with the will of the people in both the mainland and Taiwan areas, and while adhering to the goals of democracy, economic freedom, social justice and nationalization of the armed forces, jointly discuss the grand task of unification and map out a constitutional system to establish a democratic, free, and equitably prosperous China. 
Thus, the 92 consensus was carried out at the government level. Even though the main agencies of the negotiation were Association for Relations Across the Taiwan Straits (ARATS, mainland) and Straits Exchange Foundation (SEF, Taiwan), the two were established as private non-profit organizations as a matter of form, but in reality, they served the role of government agencies. Therefore, it may safely be said that the agents of the negotiation were the governments of Taiwan and China. In relation to this international negotiation, there was no direct domestic negotiation right after the 92 consensus.

Negotiations on "one China" began at the request of the Chinese side. When ARATS and SEF met for the first time in Beijing in May 1992, the main agenda of the meeting was cross-Strait "Certificates of Authentication" and "Registered Mail", the two sides exchange views without any concrete results. In the following meeting. The two sides expressed different understandings of "one China", and no results were achieved since the mainland insisted that its position on "one China" be adopted in the agreement. ${ }^{8}$

The SEF constantly insisted that it was not granted the right to discuss the one China issue by the InterAgency Mainland Affairs Committee. However, the ARATS claimed that the one China principle should be the basis for the exchanges and the working-level negotiations of the two sides, and that all problems arising from the cross-Strait exchanges should be regarded as special affairs within one country and should be resolved properly through consultation based on the one China principle. ${ }^{9}$

After cross-Straits negotiations broke down in May 1992, an agreement on the meaning of one China has taken place within Taiwanese government. President Lee Teng-hui convened the eighth meeting of the National Unification Council and made the announcement titled "About the meaning of one China". The contents of the announcement are as follows.

"Although the two sides of the Taiwan Straits are equally supportive of the 'one China' principle, their understandings are different. The PRC understands that "one China" means 'the People's Republic of China' and that after future reunification Taiwan will become one special administrative district under its jurisdiction. Our side recognizes that one China was established in 1912 and refers to the Republic of China and its sovereignty and China as a whole, but its

8 The process of 92 negotiation. http://www.sef.org.tw/lp.asp?CtNode $=4382 \& \mathrm{CtU}-$ nit $=2567 \&$ BaseDSD $=21 \& \mathrm{mp}=300 \&$ nowPage $=2 \&$ pagesize $=30$ (Accessed: 2019. 10. 28).

9 The process of 92 negotiation. http://www.gwytb.gov.cn/lhjl/la20o8q/gaikuang/201101/ t20110108_1684748.htm(Accessed: 2019. 10. 28). 
current sovereignty is limited to the Taiwan district. Taiwan is part of China, but the mainland is also part of China... As China has been divided since 1949 for a while, and it is an objective fact that the political entities of the two sides govern separately on both sides of the strait, no claims on reunification can ignore this obvious fact."

The announcement shows the Taiwanese government's official position of one China in the early 1990s. Taiwan was well aware of the differences between what Taiwan and the mainland meant by one China. Also, Taiwan claimed that both Taiwan and the mainland should admit the fact that they are now in a state of division. In Taiwan's perspective, one China did not equate to the mainland, and rather a unified China that will be achieved in the future. On the other hand, the first white paper on Taiwan issue $11^{11}$ published in the mainland in 1993 presented that People's Republic of China is the only legitimate Chinese government, and Taiwan is an inalienable part of China. It suggests that China's assertion on "one country, two systems" has been maintained since 1980s. It also reveals that the interpretations of China and Taiwan on one China were hardly negotiable.

From October 27-29, the ARATS and the SEF held a second meeting, and the representative of both the ARATS and the SEF presented five proposals on how to adhere to one China principle. On October 30, the SEF received permission from the Taiwanese government for three other proposals and delivered them to the representative of the ARATS on November 1. The proposal suggested by Taiwan was that "in the process of pursuing national unification, both sides support one China principle, but have different perceptions of what one China

10 About the meaning of "one China" https://www.mac.gov.tw/News_Content.aspx?n=AD6908DFDDB62656\&sms=161DEBC9EACEA333\&s=9E19C5DBAADFC848 (Accessed: 2019. 10. 29).

${ }^{11}$ First white paper on Taiwan issue: The Taiwan Question and Reunification of China. http:// www.china.org.cn/e-white/taiwan/index.htm (Accessed: 2019. 10. 28).

1) Only one China. There is only one China in the world, Taiwan is an inalienable part of China and the seat of China's central government is in Beijing.

2) Coexistence of two systems. On the premise of one China, socialism on the mainland and capitalism on Taiwan can coexist and develop side by side for a long time without one swallowing up the other. After reunification, Taiwan's current socio-economic system, its way of life as well as economic and cultural ties with foreign countries can remain unchanged.

3) A high degree of autonomy. After reunification, Taiwan will become a special administrative region. It will be distinguished from the other provinces or regions of China by its high degree of autonomy.

4) Peace negotiations. Peaceful reunification will greatly enhance the cohesion of the Chinese nation. It will facilitate Taiwan's socio-economic stability and development and promote the resurgence and prosperity of China as a whole. 
actually means". After the Hong Kong meeting, the head of the SEF issued a written statement on November 1, suggesting that the one China principle should be verbally explained "to the extent acceptable to each other". The ARATS appreciated that the eighth proposal of the SEF was to seek unification and maintain the one China principle, and both sides agreed on one China principle on November 16. Through the process, the two sides reached an agreement that both sides adhere to one China, with respective interpretations. ${ }^{12}$ This agreement was later called the "92 consensus." ${ }^{\text {"13 }}$

\section{THE 2000 PRESIDENTIAL ELECTION AS A CRITICAL ELECTION}

The 2000 Presidential election provoked ethnic tension and polarization among political parties surrounding the issue of unification-independence. Political parties reflected and strengthened this tendency at the same time (Schubert 2004). Taiwan had three major political parties: the KMT, the DPP, and the New Party. Before the 2000 Presidential election, James Soong left the KMT and established the PFP soon after the election ended. ${ }^{14}$

The 2000 election resulted in the first transfer of power. The KMT, which had maintained power for over 50 years, withdrew from the government. Moreover, the 2000 election fundamentally changed Taiwan's socio-political landscape (Niou \& Paolino 2003, 721). Political parties which maintained opposite perspectives on unification-independence issues were now divided into two

12 http://www.gwytb.gov.cn/lhjl/la2008q/gaikuang/201101/t20110108_1684748.htm (Accessed: 2019. 10. 28).

13 Taiwan Affairs of the State Council PRC http://www.gwytb.gov.cn/lhjl/la20o8q/gaikuang/201101/t20110108_1684747.htm (Accessed: 2019. 10. 28).

${ }^{14}$ The KMT maintained its pro-unification stance except when Lee Teng-hui announced the "two states theory." The stance of the KMT maintained that cross-Strait relations should improve practical relations, should stick to the One-China principle, and should give equal status to China and Taiwan as stipulated in Taiwan's Guidelines for National Unification in 1991. The New Party was established in 1993 after being separated from the KMT. It denied the KMT's tolerant attitude towards Taiwan independence under the leadership of Lee Teng-hui (Yu, 2005, p. 108), claiming anti-communism, anti-Taiwan independence and pro-unification. James Soong suggested a relaxation on regulations for cross-Strait exchanges, and adopted a similar position to that of the New Party toward the One-China principle (Wu, 2005, 46). The DPP was established in 1986 and was widely recognized as the "Taiwan independence party." It never acknowledged the One-China principle, but also wanted to avoid a hostile relationship with China. It continuously emphasized a practical approach toward cross-Strait issues. After the DPP received 3.8\% lower approval ratings in legislative election in 1998 than it had in 1995, and after Chen Shui-bian from the DPP lost the 1998 Taipei municipal election to Ma Ying-jeou from the KMT, the DPP realized that most of the voters did not want radical changes in Taiwanese constitutional order, and the party adjusted to a more moderate political course. 
camps: the pro-independence Pan-green camp (DPP) and the pro-unification Pan-blue camp (KMT, New Party, PFP) (Wang 2008, 179-180; Chi, 2008).

Throughout the 1990s, the democratization process continued in Taiwan which enabled both political and social changes. In politics, party competition began due to the institutional changes; in society level, social cleavages such as ethnicity and national identity developed. Taiwanese social cleavages became magnified in politics, indicating particular criteria that divide the members of a community or sub-community into groups, which might cause conflicts among individuals, communities, or organizations (Rae \& Taylor 1970; Flanagan \& Almond 1973). ${ }^{15}$

In Taiwanese society, social cleavages developed such as income, geography, education, gender or religion. The most obvious and important social cleavages which reflect the distinct features of Taiwanese society seem to be ethnicity ${ }^{16}$ and national identity. ${ }^{17}$ Even though there are differences in perspective among studies on Taiwanese social cleavages and party system, this study does not focus on how social cleavages were reflected in political parties. The main purpose is to focus on the social cleavages that permeated the party system and that appeared as a form of unification-independence issue. ${ }^{18}$

${ }^{15}$ Relations between social cleavages and party system have been actively examined in democratic-party studies. Social cleavages theory was first discussed by Lipset and Rokkan (1967). Two historical incidents, democracy and the Industrial Revolution, created four basic cleavages: center versus periphery, state versus church, owner versus worker, and land versus industry (Lipset, Rokkan 1967, 50). These social cleavages were politicized, and stances on these cleavages determined each political party's platform, policy, and candidates.

${ }^{16}$ There are four ethnic groups in Taiwan. These groups include Aborigines, the Hoklo, the Hakka, and the Mainlanders. The Hoklo and the Hakka are altogether called as Benshengren, and the mainlanders are called as Waishengren. Han people, including Benshengren and Waishengren make up for $97 \%$ of the population, the Aborigines for $2 \%$ and foreigners, people from Macau and Hong Kong, marital immigrants account for 1\%. Executive Yuan Website: https://www.ey.gov.tw/ state/News_Content3.aspx?n=7C222A52A6o66oEC\&sms=3DDA3041F685942A\&s=FFD5D521BBC119F8. Accessed: 2019. 06. 04).

${ }^{17}$ National identity can be defined as the psychological attribution of an individual to a political community that is tied to characteristics distinguishable from other communities (Gellner 1983; Smith 1991).

${ }^{18}$ There are two strands of studies on Taiwanese social cleavages and party system; one is applying social cleavages theory, and the other is using party realignment theory (Key 1955; Petrocik 1981; Sundquist 1983). The former one focuses on the structural characteristic of the cleavages, explaining that political parties absorb these social cleavages. The latter one emphasizes rather active behaviors of parties, viewing that political parties actively utilize social cleavages and mobilize voters. In the first group, Yu Ching-hsin (2005), Hsieh (2005), and Sheng \& Chen (2003) applied social cleavages theory to analyze Taiwanese political parties. In the second group, Chi (2009) analyzed Taiwan's party system using party realignment theory and revealed that political elites, mostly from the DPP, actively utilized the independence issue and developed it into a salient issue in party com- 
According to the survey conducted after the 2000 Presidential election, the data showed that major social cleavages such as ethnicity and national identity correlated with perspectives on unification-independence issue, as well as party support.

Table 1. Ethnicity and Unification-Independence after the 2000 Presidential Election

\begin{tabular}{|c|c|c|c|c|c|c|c|c|c|}
\hline & $\begin{array}{l}\text { Highly support } \\
\text { independence }\end{array}$ & $\begin{array}{c}\text { Support } \\
\text { independence }\end{array}$ & $\begin{array}{l}\text { Independence } \\
\text { if the status- } \\
\text { quo cannot } \\
\text { be maintained }\end{array}$ & $\begin{array}{l}\text { Highly support } \\
\text { unification }\end{array}$ & $\begin{array}{l}\text { Support } \\
\text { unification }\end{array}$ & $\begin{array}{l}\text { Unification if } \\
\text { the status-quo } \\
\text { cannot be } \\
\text { maintained }\end{array}$ & Status-quo & $\begin{array}{l}\text { Others/ } \\
\text { No Response }\end{array}$ & Total \\
\hline Benshengren & $\begin{array}{c}101 \\
(8 \%)\end{array}$ & $\begin{array}{c}199 \\
(16 \%)\end{array}$ & $\begin{array}{c}255 \\
(21 \%)\end{array}$ & $\begin{array}{c}42 \\
(3 \%)\end{array}$ & $\begin{array}{c}162 \\
(13 \%)\end{array}$ & $\begin{array}{c}192 \\
(16 \%)\end{array}$ & $\begin{array}{c}123 \\
(10 \%)\end{array}$ & $\begin{array}{c}137 \\
(11 \%)\end{array}$ & $\begin{array}{c}1211 \\
(100 \%\end{array}$ \\
\hline $\begin{array}{l}\text { Indigenous } \\
\text { People }\end{array}$ & 0 & $\begin{array}{c}1 \\
(9 \%)\end{array}$ & 0 & $\begin{array}{c}2 \\
(18 \%)\end{array}$ & $\begin{array}{c}2 \\
(18 \%)\end{array}$ & $\begin{array}{c}3 \\
(27 \%)\end{array}$ & $\begin{array}{c}1 \\
(9 \%)\end{array}$ & $\begin{array}{c}2 \\
(18 \%)\end{array}$ & $\begin{array}{c}11 \\
(100 \%)\end{array}$ \\
\hline Waishengren & $\begin{array}{c}2 \\
(1 \%)\end{array}$ & $\begin{array}{c}13 \\
(7 \%)\end{array}$ & $\begin{array}{c}22 \\
(12 \%)\end{array}$ & $\begin{array}{c}22 \\
(12 \%)\end{array}$ & $\begin{array}{c}43 \\
(23 \%)\end{array}$ & $\begin{array}{c}57 \\
(31 \%)\end{array}$ & $\begin{array}{c}13 \\
(7 \%)\end{array}$ & $\begin{array}{c}11 \\
(6 \%)\end{array}$ & $\begin{array}{c}183 \\
(100 \%)\end{array}$ \\
\hline $\begin{array}{c}\text { Others/ } \\
\text { No Response }\end{array}$ & 0 & 0 & 2 & 1 & 0 & 0 & 0 & 1 & 4 \\
\hline Total & 103 & 213 & 279 & 67 & 207 & 252 & 137 & 151 & 1409 \\
\hline
\end{tabular}

Data: Gongyuan erqiannian zongtong daxuan xuanmin toupiao hang wei yanjiu (Voting Behavior in 2000 Presidential Election)

As we can see from table $<1>$, Benshengrens are likely to support independence (45\%: Highly support independence + Support independence + Independence if the status-quo cannot be maintained). On the other hand, Waishengrens are less likely to support independence, and most of them support unification (66\%: Highly support unification + Support unification + Unification if the status-quo cannot be maintained).

Table 2. National Identity and Unification-Independence after the 2000 Presidential Election

\begin{tabular}{|c|c|c|c|c|c|c|c|c|c|}
\hline & $\begin{array}{l}\text { Highly support } \\
\text { independence }\end{array}$ & $\begin{array}{c}\text { Support } \\
\text { independence }\end{array}$ & $\begin{array}{l}\text { Independence } \\
\text { if the status- } \\
\text { quo cannot } \\
\text { be maintained }\end{array}$ & $\begin{array}{l}\text { Highly support } \\
\text { unification }\end{array}$ & $\begin{array}{l}\text { Support } \\
\text { unification }\end{array}$ & $\begin{array}{l}\text { Unification if } \\
\text { the status-quo } \\
\text { cannot be } \\
\text { maintained }\end{array}$ & Status-quo & $\begin{array}{l}\text { Others/ } \\
\text { No Response }\end{array}$ & Total \\
\hline Taiwanese & $\begin{array}{c}79 \\
(16 \%)\end{array}$ & $\begin{array}{c}116 \\
(23 \%)\end{array}$ & $\begin{array}{c}13 \\
(3 \%)\end{array}$ & $\begin{array}{c}38 \\
(8 \%)\end{array}$ & $\begin{array}{c}113 \\
(22 \%)\end{array}$ & $\begin{array}{c}35 \\
(7 \%)\end{array}$ & $\begin{array}{c}41 \\
(8 \%)\end{array}$ & $\begin{array}{c}69 \\
(14 \%)\end{array}$ & $\begin{array}{c}504 \\
(100 \%)\end{array}$ \\
\hline Chinese & $4(3 \%)$ & $\begin{array}{c}8 \\
(5 \%)\end{array}$ & $\begin{array}{c}26 \\
(18 \%)\end{array}$ & $\begin{array}{c}43 \\
(29 \%)\end{array}$ & $\begin{array}{c}14 \\
(10 \%)\end{array}$ & $\begin{array}{c}41 \\
(28 \%)\end{array}$ & $\begin{array}{c}8 \\
(5 \%)\end{array}$ & $\begin{array}{c}3 \\
(2 \%)\end{array}$ & $\begin{array}{c}147 \\
(100 \%)\end{array}$ \\
\hline $\begin{array}{l}\text { Taiwanese/ } \\
\text { Chinese }\end{array}$ & $\begin{array}{c}18 \\
(3 \%)\end{array}$ & $\begin{array}{c}88 \\
(12 \%)\end{array}$ & $\begin{array}{c}27 \\
(4 \%)\end{array}$ & $\begin{array}{c}123 \\
(17 \%)\end{array}$ & $\begin{array}{c}151 \\
(21 \%)\end{array}$ & $\begin{array}{c}173 \\
(24 \%)\end{array}$ & $\begin{array}{c}80 \\
(11 \%)\end{array}$ & $\begin{array}{c}55 \\
(8 \%)\end{array}$ & $\begin{array}{c}715 \\
(100 \%)\end{array}$ \\
\hline $\begin{array}{l}\text { Others/ } \\
\text { No response }\end{array}$ & 2 & 1 & 2 & 2 & 1 & 3 & 9 & 22 & 42 \\
\hline Total & 103 & 213 & 68 & 206 & 279 & 252 & 138 & 149 & 1408 \\
\hline
\end{tabular}

Data: Gongyuan erqiannian zongtong daxuan xuanmin toupiao hang wei yanjiu (Voting Behavior in 2000 Presidential Election)

petition, forming a polarized competition. 
Also, in terms of national identity, people who identified themselves as Taiwanese were more likely to support independence (42\%: Highly support independence + Support independence + Independence if the status-quo cannot be maintained) than to support unification (37\%: Highly support unification + Support unification + Unification if the status-quo cannot be maintained). On the other hand, people who believed themselves as Chinese tended to support unification (67\%: Highly support unification + Support unification + Unification if the status-quo cannot be maintained), and only $26 \%$ of them (Highly support independence + Support independence + Independence if the status-quo cannot be maintained) supported Taiwanese independence.

Table 3. Ethnicity and Party Support after the 2000 Presidential Election

\begin{tabular}{|c|c|c|c|c|c|c|c|}
\hline & KMT & DPP & $\begin{array}{l}\text { New } \\
\text { Party }\end{array}$ & PFP & None & $\begin{array}{c}\text { No } \\
\text { response }\end{array}$ & Total \\
\hline Benshengren & $\begin{array}{c}193 \\
(15.9 \%)\end{array}$ & $\begin{array}{c}361 \\
(29.8 \%)\end{array}$ & $\begin{array}{c}7 \\
(0.57 \%)\end{array}$ & $\begin{array}{c}130 \\
(10.7 \%)\end{array}$ & $\begin{array}{c}500 \\
(41.2 \%)\end{array}$ & $\begin{array}{c}20 \\
(1.65 \%)\end{array}$ & $\begin{array}{c}1211 \\
(99.82 \%)\end{array}$ \\
\hline $\begin{array}{l}\text { Indigenous } \\
\text { People }\end{array}$ & $\begin{array}{c}4 \\
(36.4 \%)\end{array}$ & 0 & 0 & $\begin{array}{c}5 \\
(45.5 \%)\end{array}$ & $\begin{array}{c}2 \\
(18.1 \%)\end{array}$ & 0 & $\begin{array}{c}11 \\
(100 \%)\end{array}$ \\
\hline Waishengren & $\begin{array}{c}44 \\
(24 \%)\end{array}$ & $\begin{array}{c}14 \\
(7.8 \%)\end{array}$ & $\begin{array}{c}7 \\
(3.8 \%)\end{array}$ & $\begin{array}{c}81 \\
(44 \%)\end{array}$ & $\begin{array}{c}36 \\
(19.9 \%)\end{array}$ & $\begin{array}{c}1 \\
(0.5 \%)\end{array}$ & $\begin{array}{c}183 \\
(100 \%)\end{array}$ \\
\hline Others & 1 & 0 & 0 & 0 & 0 & 0 & 1 \\
\hline No response & 1 & 0 & 0 & 1 & 1 & 0 & 3 \\
\hline Total & 243 & 375 & 14 & 217 & 539 & 21 & 1409 \\
\hline
\end{tabular}

Data: Gongyuan erqiannian zongtong daxuan xuanmin toupiao hang wei yanjiu (Voting Behavior in 2000 Presidential Election), Chi (2009b).

With regard to Ethnicity and party support, about $70 \%$ of Waishengren approved of the KMT, the New Party, and the People First Party (PFP). In 2000, there was a clear distinction in voting behavior between Benshengren and Waishengren; while only $10 \%$ of Waishengren supported the DPP, they firmly supported a Pan-blue camp. 
Table 4. National Identity and Party Support after the 2000 Presidential Election

\begin{tabular}{cccccccc}
\hline & KMT & DPP & $\begin{array}{c}\text { New } \\
\text { Party }\end{array}$ & PFP & None & $\begin{array}{c}\text { No } \\
\text { response }\end{array}$ & Total \\
\hline Taiwanese & 49 & 217 & 2 & 19 & 206 & 11 & 504 \\
& $(9.7 \%)$ & $(43 \%)$ & $(0.4 \%)$ & $(3.7 \%)$ & $(40.8 \%)$ & $(2.18 \%)$ & $(99.78 \%)$ \\
Chinese & 50 & 14 & & 36 & 46 & 1 & 147 \\
Taiwanese/ & $(34 \%)$ & $(9.5 \%)$ & 0 & $(24.4 \%)$ & $(31 \%)$ & $(0.6 \%)$ & $(99.5 \%)$ \\
Chinese & $(19 \%)$ & $(19.4 \%)$ & $(1.67 \%)$ & $(22.2 \%)$ & $(36.7 \%)$ & $(0.7 \%)$ & $(99.67 \%)$ \\
Others & 0 & 1 & 0 & 0 & 3 & 1 & 5 \\
No response & 6 & 4 & 0 & 1 & 16 & 2 & 29 \\
Total & 242 & 375 & 14 & 217 & 539 & 21 & 1408 \\
\hline
\end{tabular}

Data: Gongyuan erqiannian zongtong daxuan xuanmin toupiao hang wei yanjiu (Voting Behavior in 2000 Presidential Election), Chi (2009b).

With respect to national identity and party support, Yu (2005) analyzed legislative elections from 1995 to 2004 and proved that people who were native Taiwanese and identified as Taiwanese tended to support the DPP. While those who identified as Chinese supported the parties that belonged to Pan-blue camp (Yu 2005, 115). In addition, as we can see from the table above, there was a clear relation between national identity and party support after the 2000 Presidential election. $43 \%$ of the people who identified themselves as Taiwanese supported the DPP, while only $15 \%$ supported the Pan-blue camp. Conversely, $54.4 \%$ of those who identified as Chinese supported the Pan-blue camp, while only $9.5 \%$ supported the DPP.

Table 5. Presidential Candidates and Polls for the 2000 Election

\begin{tabular}{cccccc}
\hline & KMT & DPP & New Party & Independent & Independent \\
\hline \multirow{2}{*}{ Candidates } & $\begin{array}{c}\text { Lien Chan Siew } \\
\text { Wanchang }\end{array}$ & $\begin{array}{c}\text { Chen Shuibian Lu } \\
\text { Hsiu-lien }\end{array}$ & $\begin{array}{c}\text { Li Ao Fung } \\
\text { Huhsiang }\end{array}$ & $\begin{array}{c}\text { Hsu Hsin-liang } \\
\text { Josephine Chu }\end{array}$ & $\begin{array}{c}\text { James Soong } \\
\text { Chang } \\
\text { Chauhsiung }\end{array}$ \\
Votes & $23.1 \%$ & $39.3 \%$ & $0.13 \%$ & $0.63 \%$ & $36.84 \%$ \\
\hline
\end{tabular}

Source: Data retrieved from Central Election Commission of Taiwan. http://db.cec.gov.tw/histMain.jsp?voteSel=19981201B1.

In 2000 Presidential election, Chen Shui-bian from the DPP won the election in 2000. He won 39.3\% approval. James Soong followed with $36.84 \%$ while the KMT only obtained $23.1 \%$ of votes. The development of social cleavages in Taiwan in the 1990s, and their absorption into political parties led to an 
unintended result of a Level II negotiation on the 92 consensus. Political parties were divided into two group, one supporting unification with China (Pan-blue camp) and one supporting Taiwan independence (Pan-green camp). The 2000 election can be defined as a "critical election" (Chi 2009a; Chi 2009b; Yu 2005). The critical election led to sharp changes in issues, party leaders, regional and demographic bases of power of the two parties, and the structure or rules of the political system. ${ }^{19}$ In Taiwan's case, the unification-independence issue became the borderline between political parties. The pro-independence party came into power, implying fundamental changes in Taiwan's China policy and cross-Strait relations.

The 2000 Presidential election yielded Taiwan's "involuntary defection". Voluntary defection describes a situation in which a rational actor intentionally breaks a promise when there is no compulsory contract. Involuntary defection indicates an actor's unintentional violation of contract, resulting from a failure in domestic ratification. Although the Taiwanese government did not intend to break the 92 consensus (Level I), Taiwan's official position became "Taiwan independence" as a result of socio-political changes (Level II ) during the election. China's military threat was not a good option for two reasons. First, China had ineffectively threatened Taiwan by force throughout the 1990s, but Taiwanese residents' confidence in Chinese government showed a sharp decline, while support for Taiwan's independence largely increased during this period (Woei \& Yu 2001). ${ }^{20}$ In addition, an actual military conflict between Taiwan and China was never possible, due to the actions of the United States. ${ }^{21}$ As China's main purpose was to protect the One-China principle, fostering a negotiation

\footnotetext{
${ }^{19}$ The notion of the "critical election" by Key refers to observed changes in domestic politics; in his work he states that political realignment is complete, when new political cleavages form after a critical election, and continue for decades (Key 1955, 4).actively utilized the independence issue and developed it into a salient issue in party competition, forming a polarized competition.

${ }^{20}$ Tung (2002b) analyzed how China's military threat in the late 1990s strengthened Taiwan's separatism, using survey results conducted by Taiwan's Mainland Affairs Council. According to the study, after July 1995, when China first conducted military exercises in Taiwan Strait, separatism in Taiwan was reinforced; from 1998 to 1999 when cross-Strait maintained relatively peaceful relations, however, separatism was weakened. When China again conduced a military threat from 1999 to 2000, separatism resurged (Tung 2002b, 9). Cheng \& Wang (2001) observed similar results; the more China provoked Taiwan, the more Taiwanese residents incite their politicians to stray from moderate attitudes regarding issues of independence. They then require politicians to define Taiwan's sovereignty clearly and to protect Taiwan's residents from mainland China (Cheng \& Wang 2001).

${ }^{21}$ Throughout the 1990 and the early 2000s, China did not possess a strong second nuclear attack capability against the United States. Chinese military elites recognized that the United States had the advantage in traditional military capabilities, and it would be impossible for China to make a frontal attack against the United States (Kim \& Park 2004).
} 
with Taiwan was a more realistic option than taking a military action.

\section{THE CHANGES IN BARGAINING POWER BETWEEN TAIWAN AND CHINA AND CHINA'S STRATEGY}

Following social and political changes in Taiwan, Taiwan government's winset for the One-China principle was reduced to "Taiwan's independence." The bargaining power of China and Taiwan is summarized below. Except for the innate characteristic of the regimes ${ }^{22}$ the size of win-set is reduced when the issue is politicized, cost of no-agreement is low and domestic interests are heterogeneous. The unification-independence issue was politicized and interests of each domestic group on the issue were heterogeneous in Taiwan. On the other hand, cost of no-agreement on the unification is higher for China since the issue is one of its core interests. Therefore, Taiwanese win-set was reduced and its bargaining power was enlarged, while China experienced the opposite.

Table 6. Bargaining Power after the 2000 Presidential Election

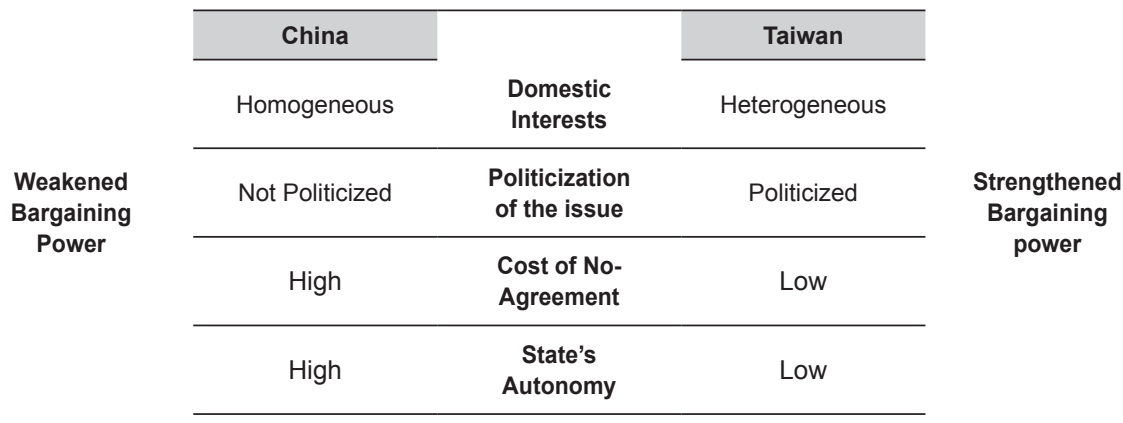

Under this circumstance, China had two options to derive a negotiable space between the two sides. One was to expand its win-set, and the other was to expand Taiwan's win-set. Since the Chinese government has relative authority from public pressure, China expanded its win-set in order to make an agreement with the Taiwanese government.

\footnotetext{
${ }^{22}$ Government that is more autonomous normally has larger win-set, since it is free from negotiations with its own domestic groups.
} 
Figure 2. Taiwan's Win-set after the 2000 Presidential Election and the Strategy of Chinese Government

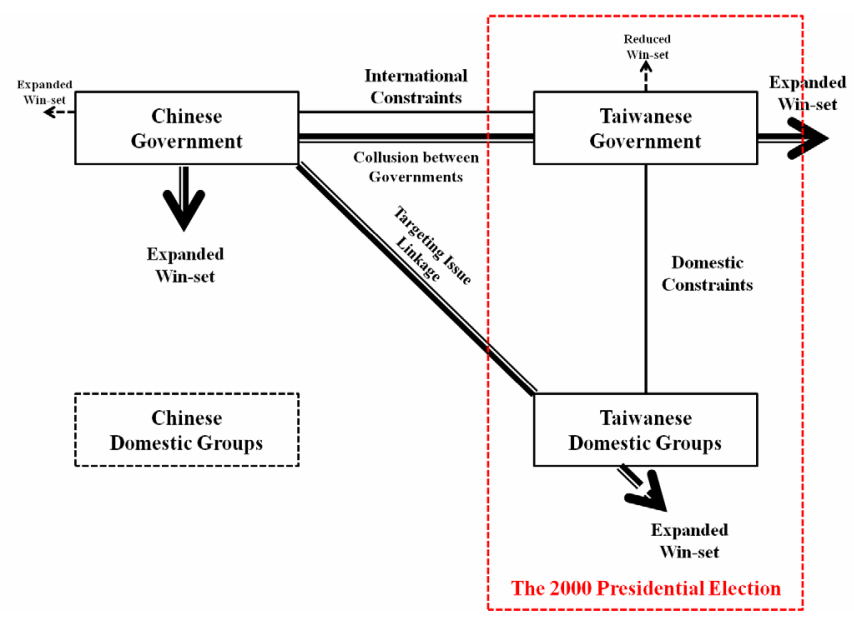

\section{EXPANDING CHINA'S WIN-SET}

Right after Chen Shui-bian won the election China claimed to put aside political issues and to promote cooperation in non-political areas. While China had previously insisted that political negotiation should precede economic and cultural exchanges, it changed its stance after the cross-Strait crisis in 19951996. The change was to claim that the two sides could proceed with "three-links" without bringing up political issues. As Chen Shui-bian made the announcement "one country on each side", China firstly warned the Taiwanese independence movement (Yan 2011, 32). But unlike its previous stances, China did not make any military threat. In 2001, China claimed that it should join the WTO first and Taiwan would join as "Chinese Taipei". However, Taiwan was later allowed to join the WTO as an independent entity (BBC News, 2001, November 11).

By addressing the least political issues in cross-Strait relations, China tried to increase the possibility of negotiation. China's win-set on the One-China principle issue showed an explicit change in Jiang Zemin's Report at the 16th Party Congress in 2002. Jiang Zemin stipulated a new definition that both the mainland and Taiwan belong to China. Adopting a new definition indicated that China approved the definition which Taiwan had stipulated in "Taiwan's Guidelines for National Unification" in 1991. Ultimately, China expanded its win-set to the degree in which the KMT had agreed upon in the early $1990 \mathrm{os}$. 
While China pursued a practical interaction with the DPP, it tried to promote political and non-political cooperation with the Pan-blue camp, which supported the One-China principle.

\section{CHINA'S STRATEGY TO EXPAND TAIWAN'S WIN-SET: TARGETING IS-} SUE-LINKAGE STRATEGIES

China approached Taiwanese business community and political parties other than the DPP in order to isolate the DPP (Eiichi Ohshima 2010, 7) and to manipulate the Pan-blue camp to seize power in the following Taiwanese elections. Thus, China targeted both Taiwanese politicians from the Pan-blue camp and Taiwanese businessmen in China. The Pan-blue camp was also motivated to cooperate with China after the 2000 Presidential election. After losing the election, these parties had to consolidate their domestic foundation by establishing their "economic development" image of pro-China and unification. For example, in January 2001, their legislative members visited China and Qian Qichen, who was a member of politburo of the CCP and the vice premier of the State Council. They were granted an audience with the delegation from the New Party and the KMT. Personnel Chinese government greeted the legislative members from Taiwan and exchanged their perspectives on new air routes between the two sides and the practices of the three-links (Yu \& Jia 2011, 571). In April of the same year, Liu Sung-pan, the former president of the Legislative Yuan, and other legislators visited Beijing and had a round-table talk with the ARATS and relevant departments to discuss the "three-links." Although these discussions on the three-links between Taiwanese Pan-blue camp and China did not result in an agreement, they lay a foundation for later practices (Yu \& Jia $2011,571)^{23}$

A similar strategy was used to target Taiwanese running businesses in mainland China. Since the relations between the ARATS and the SEF ceased, the Chinese government placed emphasis on Taiwanese businessmen's political role from the 2000s. (Lee 2011, 74-75). The Chinese government linked these businessmen's economic interests with its own political goal and encouraged the Taiwanese government to implement an open policy toward China. For example, in 2003, a Taiwanese flight flew from Shanghai went on to Taipei with 243 passengers. Technically, this flight was not direct, but historically it was the first commercial flight from Taiwan to China since 1949. Although the

\footnotetext{
${ }^{23}$ Formal exchanges between the KMT and the CCP began after 2005, with the start of Chen Shui-bian's second term, defined as the Cross-Strait Economic, Trade, and Culture Forum.
} 
Taipei government never officially acknowledged that this special flight occurred because of pressure from the business community, the special direct flight started after several negotiations among Taiwan Business Association (TBA) leaders from Shanghai, Xiamen, Dongguan, Shenzhen, and Beijing, and the Taiwanese government. These actions suggest that Taiwanese business people in China had been gradually transformed from simple investors into the Taipei government's mainland policy consultants (Lee 2011, 32).

From 2000 to 2004, the Chinese government realized the potential of Taiwanese investors as tools to promote cross-Strait reunification. As a result, the interaction between Taiwanese businesses and local governments developed in multiple layers (Lee 2011, 83) 24 $^{24}$ According to the study conducted by Gunter and Keng in 2012, because of a new wave of Taiwanese investment and migration that reached China after the 1997 Asian financial crisis, a younger and well-educated generation of Taiwanese businesspeople went to the mainland. Many of this 'second generation', Taishang invested in high tech industries, particularly in the Shanghai/Kunshan area. Age, time of arrival, and opportunity due to China's developing economy all impacted the overall political outlook of the Taishang constituency, and a huge percentage were much more supportive of the KMT's pro-integration stance (Gunter \& Keng 2012, 147). The Chinese authorities were also reported to 'encourage' Taishang to return to Taiwan to cast their ballot, clearly in the hope that they would vote for the 'pro-China' Kuomintang. TBAs were reported to have organized campaign and donation banquets in multiple Chinese cities and to have offered cheap air tickets in efforts to persuade larger numbers of Taishang to vote in Taiwan's elections (Shubert 2013, 58).

\footnotetext{
${ }^{24}$ For instance, Taiwanese investors were allowed to attend local People's Congress or Political Committee meetings below the provincial level. Above the provincial level, governmental bureaus invited Taiwanese businesspeople as consultants (United Daily, 2002, December 12, as cited in Lee 2008, 159). In the Jiangsu province in 2003, Taiwanese businessmen were invited to attend the opening ceremony of the 17th Jiangsu Provincial People's Congress for the first time and listen to the "government work report" (East Today, 2003, February 17). In Tianjin, the governmental departments and representatives of more than 40 Taiwan-funded enterprises attended the 28th "Tianjin Taiwanese Investment Environment Symposium" and listened to the voices of Taiwanese businessmen in 2003. In response to the difficulties and troubles in the investment of Taiwanese businessmen, the departments of the Tianjin Municipal Government proposed solutions to improve investment environment (East Today, 2003, March 1). Lee (2008) argues that although Taiwanese investors began to participate at higher levels of local Chinese political affairs, this change still reflected the Chinese government's calculated self-interest and its dominance over interactions with Taiwanese investors (Lee 2008, 252). Considering that Chen Shui-bian won by 313,000 votes in 2000 election, it was important for Chinese government to mobilize Taiwanese businessmen in Taiwan elections.
} 


\section{CONCLUSION}

This study explores how Taiwanese domestic politics in the 1990s influenced China's Taiwan policy in the early 2000s. To illustrate this, this paper borrowed Robert Putnam's discussion of the linkage between domestic politics and international politics in two-level game theory. Using a two-level analysis, this paper analyzed how Taiwanese social cleavages in the 1990 s led to a change not only in its domestic politics but ultimately in China's Taiwan policy. Furthermore, this study revisits the classical two-level game theory and examines the relevance of it.

Taiwan's social cleavages such as ethnicity and national identity have erupted throughout democratic transition in the 1990s, as were reflected in the political party system. As a result, political parties were divided into two camps, and the unification or independence issues became the borderline between them. Furthermore, as the pro-independence party came into power, Taiwan's China policy and cross-Strait relations encountered fundamental changes. Taiwan's ruling party's claim independence, which means that Taiwan betrayed the "92 consensus" on the One-China principle reached between China and Taiwan. However, instead of using military threat China tried to expand the possibility of consensus with Taiwan. China expanded its win-set first and then interacted both with Taiwanese politicians from the Pan-blue camp and with Taiwanese businessmen in China for the purposes of expanding Taiwan's win-set.

This study focused on the importance of Taiwanese domestic politics in crossStrait relations, challenging previous studies that have emphasized the impact of the US-China relations or of Chinese diplomatic strategy on cross-Strait relations. This paper highlights that not only the Taiwanese government but also the Taiwanese social dynamics influenced cross-Strait relations. In addition, this study revealed that political decisions of weaker countries were not necessarily determined by the great powers in cross-Strait relations or by international relations. Rather, bargaining powers could be reconstructed and reversed according to the characteristics of the issues.

From a theoretical perspective, this study revisited two-level game theory and applied it to cross-Strait relations to examine the theory's relevance. Although Putnam's discussion received great attention upon its release, most foreign policy theories or bargaining theories still take a state-centric perspective. This study reveals the significance of the linkage between domestic and international perspective, and theoretical relevance of the two-level game theory.

Cross-strait relations have continued to repeat political ups and downs from the beginning. The reality is that cross-strait relations and Taiwan are being 
discussed under the structure of U.S.-China relations, especially as parts of the U.S.-China conflicts 2000s. However, such a discussion is an approach that ignores the autonomous space of relative weaker countries in international politics, and has the limitation of the argument that in reality cannot be analyzed accurately. Therefore, this study hopes that the discussion of relations between countries will break away from the one-way explanation that great powers affect weak countries.

\section{REFERENCES}

Almond, Gabriel Abraham \& Scott C. Flanagan, \& Robert John Mundt (eds.). 1973. Crisis, choice, and change: historical studies of political development. Boston: Little, Brown.

Association for Relations Across the Taiwan Straits. www.arats.com.cn

BBC News. 2001. "Taiwan joins China in WTO". (November 11). Accessed at http://news.bbc.co.uk/2/hi/business/1650169.stm (June 1, 2018).

Central Election Commission of Taiwan. http://db.cec.gov.tw/histMain. jsp?voteSel=19981201B1.

Cheng, Tunjen, \& Vincent Weicheng Wang. 2001. "Theoretical constructs: between convergence and collision: whither cross-Strait relations?" Cambridge Review of International Affairs 14(2), 239-256.

Chen, C. K. 2009. "China and Taiwan: A future of peace." Josef Korbel Journal of Advanced International Studies 1(1), 14-25.

Chi, Eunju. 2009a. "Independence issues and party realignment in Taiwan after democratic transition." Korean Political Science Review 43(1), 203-227. . 2009b. Independence Issues and Taiwan's Party Politics. Paju: Nanam.

. 2008. "Polarized Competition of Party System and Parties' Ideologies in Taiwan after Democratic Transition." Korean journal of international relations 48(4), 329-356.

China Business Times. 2002. "The preferential treatment for Taiwanese companies remains unchanged". (September 10). Accessed at http:// finance.sina.com.cn/roll/20020910/0630252462.html (June 1, 2018). . 2003. "Beijing and Shanghai's real offer".(October 14). Accessed at http://finance.sina.com.cn/roll/20031014/1302474929.shtml (June 1, 2018).

China news. 2013. "How much do Taiwanese businessmen influence on the 
Presidential election?”. (November 9). Accessed at http://www.china. com.cn/zhuanti2005/txt/2003-11/19/content_5445110.htm (June 3, 2018).

Choi, Eunbong \& Do Young Gong. 2018. "Contested statehood as an apparatus of sovereignty in East Asia: Taiwan's entry-exit policy.” Journal of Peace and Unification 8(1), 1-21.

Choi, G. H. 2011. Taiwan's mainland policy. Seoul: Munsacheol.

Chou, C. C. 2018. "Contending Notions of the Cross-Strait Status Quo in Taiwan and Across the Strait: Impacts on US-Taiwan Relations." China Review, 18(3), 121-148.

Copper, John F. 2000. "Taiwan's 2000 presidential and vice presidential election: Consolidating democracy and creating a new era of politics." Maryland Series in Contemporary Asian Studies 2000 2(1), 1-90.

East, M. A., Salmore, S. A., \& Hermann, C. F. 1978. Why nations act: theoretical perspectives for comparative foreign policy studies. Beverly Hills: Sage Publications, Inc.

East Today. 2003. "Foreign and Taiwanese businessmen'first participation in Chinese People's Political Consultative Conference of Jiangsu province". (February 17). Accessed at http://www.eastday.com/ epublish/gb/paper148/20030217/class014800003/hwz886125.htm (June 3, 2018). . 2003. "Tianjin convened government functional departments to listen to problems regarding Taiwanese investment." (March 1). Accessed at http://www.eastday.com/epublish/gb/paper148/20030301/ class014800003/hwz894577.htm (June 5, 2018).

Eiichi, Ohshima. 2010. "The progress in Cross-Strait economic relations and Taiwan's autonomy." Zaidanhōjin kōryū kyōkai center's Japan-Taiwan research support report in 2009. Tokyo: Zaidanhōjin kōryū kyōkai.

Embassy of the People's Republic of China in the United States of America. www.china-embassy.org/eng/zt/twwt/White\%20Papers/t36705.htm.

Executive Yuan Website. https://www.ey.gov.tw/state/News_Content3.aspx? $\mathrm{n}=7 \mathrm{C} 222 \mathrm{~A} 52 \mathrm{~A} 60660 \mathrm{OC} \& \mathrm{sms}=3 \mathrm{DDA} 3041 \mathrm{~F} 685942 \mathrm{~A} \& \mathrm{~s}=\mathrm{FFD} 5 \mathrm{D} 521 \mathrm{~B}-$ $\mathrm{BC} 119 \mathrm{~F} 8$.

Gellner, Ernest. 1983. Nations and nationalism. Paris: Payot.

Han, Jong Soo \& Chou, Wei Chen. 2005. "The Unification Policies of China and Taiwan and Their Mutual Exchanges and Cooperation." History and Society 35, 9-26.

Hickey, D. V. 2009. "Beijing's evolving policy toward Taipei: engagement or entrapment.” Issues \& Studies 45(1), 31-70. 
Hopmann, P. Terrence. 1995. "Two paradigms of negotiation: bargaining and problem solving." The Annals of the American Academy of Political and Social Science 542(1), 24-47.

Hsieh, John Fuh-sheng. 2005. "Ethnicity, national identity, and domestic politics in Taiwan." Journal of Asian and African Studies 40(1-2), 1328.

Hsieh, John Fuh-sheng \& Niou, Emerson. 1996. "Salient issues in Taiwan's electoral politics." Electoral Studies 15(2), 219-235.

Iida, K. 1996. "Involuntary defection in two-level games." Public Choice 89(34), 283-303.

Jung, C. G. 2006. "The Changes and Future Perspectives of the Functional Relationship between the China and the Taiwan under the Unification." Journal of North-East Asian Studies 40, 79-104.

Jung, G. W. 2002. Two-Face Game: An Alternative to Robert D. Putnam's Two-Level Game Theory. Korean Journal of International Relations 42(4), 49-72. . 2006. "North Korea's nuclear negotiations based on the logic of the two-face game.” North Korean Studies 5, 131-168.

Kan, Shirley A. 2014. "China/Taiwan: evolution of the "One China" policy-key statements from Washington, Beijing, and Taipei." Library of Congress Washington DC Congressional Research Service.

Katzenstein, Peter J., Eds. 1978. Between power and plenty: foreign economic policies of advanced industrial states. Madison: University of Wisconsin Press.

Keng, Shu \& Gunter Schubert. 2012. "Taishang as a factor shaping Taiwan's domestic politics." In Tsang, S. (Ed.), The Vitality of Taiwan (139-163). London: Palgrave Macmillan.

Keohane, Robert O. \& Nye, Joseph S. 1977. Power and interdependence. Boston: Little, Brown.

Key, Valdimer Orlando. 1995. Politics, parties, and pressure groups. New York: Crowell Company.

Kim, Jae Chul \& Park In Hwi. 2004. "Power relations between the U.S. and China on the Taiwan crisis and its security implications on East Asia and the Korean Peninsula." Strategic Studies, 2-86.

Kim, Ok-Joon. 2010. "Unification policy in the Mao's period: the 'One China policy' principle and subsequent policy changes." Journal of Institute for Social Sciences 21(4), 117-136.

Kim, W. S. 2002. Political Economy of Korea-Japan Economic Cooperation. Seoul: Society and Discourse 
Lee, Chun-Yi. 2011. Taiwanese business or Chinese security asset: a changing pattern of interaction between Taiwanese businesses and Chinese governments. London and New York: Routledge.

. 2008. "When private capital becomes a security asset: challenging conventional government/business interaction." East Asia 25(2), 145165 .

Lim, Y. H. 2018. "The Future Instability of Cross-Strait Relations: Prospect Theory and Ma Ying-Jeou's Paradoxical Legacy." Asian Security 14(3), 318-338.

Lin, Tse-min \& Yun-han Chu \& Melvin J. Hinich. 1996. "Conflict displacement and regime transition in Taiwan: A spatial analysis." World Politics 48(4), 453-481.

Lipset, S. M., \& Rokkan, S. 1967. Party systems and voter alignments: Crossnational perspectives. (7 vols). New York: Free press.

Lyu, Dong Won. 2000. "Taiwanese political parties' China policy and the 2000 Presidential election." The $21^{\text {st }}$ Century Political Science Association 10(1), 139-160.

Mainland Affairs Council Taiwan. https://www.mac.gov.twfour principles

Moravcsik, A. 1993. "Introduction: Integrating International and Domestic Explanations of World Politics." in Jacobson, Evans, and Putnam eds., Double-edged Diplomacy. Berkeley: University of California Press, $3-42$.

National Chengchi University Election Study Center. http://esc.nccu.edu.tw/ course/news.php?Sn=166.

Niou, Emerson \& Philip Paolino. 2003. "The rise of the opposition party in Taiwan: explaining Chen Shui-bian's victory in the 2000 Presidential election." Electoral Studies 22(4), 721-740.

O’Donnell, G. 1992. "Transitions, continuities, and paradoxes.” In Mainwaring, S., \& O'Donnell, G. A (Eds), Issues in democratic consolidation: The new South American democracies in comparative perspective. Notre Dame: University of Notre Dame Press, 17-56.

Patterson, L. A. 1997. Agricultural policy reform in the European Community: a three-level game analysis. International organization 51(1), 135-165.

People's Daily. 2000. "Premier Zhu Rongji met with Chinese and foreign journalists to answer questions from reporters at the press conference of the Third Session of the Ninth National People's Congress." (March 16). Accessed at http://www.people.com.cn/GB/ channel1/10/20000704/128925.html (June 5, 2018).

Petrocik, John R. 1981. Party coalitions: realignment and the decline of the 
new deal party system. Chicago: University of Chicago Press.

Przeworski, A. 1992. "The games of transition." In Mainwaring, S., \& O'Donnell, G. A (Eds), Issues in democratic consolidation: The new South American democracies in comparative perspective. Notre Dame: University of Notre Dame Press, 105-152.

Putnam, R. D. 1988. "Diplomacy and domestic politics: the logic of two-level games." International organization, 42(3), 427-460.

Rae, Douglas W., \& Michael Taylor. 1970. The analysis of political cleavages. New Haven: Yale University Press.

Rosenau, J. N. 1966. "Pre-theories and theories of foreign policy." In Farrell, Robert Barry (Eds), Approaches to comparative and international politics. Northwestern: Northwestern University Press, 27-92.

Schubert, Gunter. 2013. "Assessing political agency across the Taiwan strait: the case of the Taishang." China Information 27(1), 51-79.

. 2004. "Taiwan's political parties and national identity: the rise of an overarching consensus." Asian Survey 44(4), 534-554.

Sheng, Xingyuan \& Chen Yiyan. 2003. "Political cleavages and party competition: An analysis on legislative election in 2001." Xuanju yanjiu 10(1), 7-40.

Shin, Sang Jin. 2002. "Taiwanese democratization.” Journal of North-East Asian Studies 23, 155-171.

Smith, Anthony D. 1991. National identity. Reno: University of Nevada Press.

Sohu News. 2004. "Wubangguo: the Standing Committee of NPC carefully handles proposals." (March 10). Accessed at http://news.sohu. com/2004/03/10/07/news219380745.shtml (June 1, 2018).

Straits Exchange Foundation. www.sef.org.tw

Su, Chi. trans. Chi, Eun-ju. 2017. Taiwan and China, 20 years of Cross-Strait relations. Seoul: Korea University Press.

Sundquist, James L. 1983. Dynamics of the party system. Washington, DC: Brookings Institute.

Survey Research Data Archive. 2003. "Voting Behavior in 2000 Presidential Election." (August 1). Accessed at https://srda.sinica.edu.tw/ datasearch_detail.php?id=1641 (May 25, 2018).

Taiwan Affairs of the State Council PRC. http://www.gwytb.gov.cn/lhjl/ la2008q/gaikuang/201101/t20110108_1684747.htm.

Tung, Chen-yuan. 2003. "Cross-Strait economic relations: China's leverage and Taiwan's vulnerability." Issues and Studies 39(3), 137-176.

. 2002a. "Chinese Taiwan policy: Changes, characteristics and variables." In Ding, Arthur (Eds), Challenges in Hu Jintao's era. Taipei: 
Xinxinwen Chubanshe, 312-345. . 2002b. "Taiwanese China policy and reaction during the military threat in 1995-96 and 1999-2000." Zhongguo Shiwu 9, 71-89.

Walton, Richard E., \& Robert B. McKersie. 1965. A behavioral theory of labor negotiations: An analysis of a social interaction system. Ithaka: Cornell University Press.

Woei, Tsai George \& Yu, Peter Kien-hong. 2001. Taiwanisation: its origin and politics. Vol. 31, Singapore: World Scientific.

Wei, Chi-hung. 2015. "China-Taiwan relations and the 1992 consensus, 2000-2008." International Relations of the Asia-pacific 16(1), 67-95.

Wu, Yu-Shan. 2004. "Taiwanese nationalism and its implications: testing the worst-case scenario." Asian Survey 44(4), 614-625.

Xin, Qiang. 2009. "Mainland China's Taiwan policy adjustments." China Security 5(1), 53-64.

Yan, Anlin. 2011. "Cross-Taiwan straits relations and Beijing's Taiwan policy adjustment since 1979." World Scientific, 21-50.

Yu, Ching-hsin. 2005. "The evolving party system in Taiwan, 1995-2004." Journal of Asian and African Studies 40(1-2), 105-123.

$\mathrm{Yu}, \mathrm{Keli}$, Jia, Yaobin (Eds). 2011. Cross-Strait inter party relations in 90 years. Beijing: Jiuzhou chubanshe.

[Received Aug 6, 2019; Revised Sep 20, 2019; Accepted Nov 13, 2019] 
